Review Article

\title{
Stingless Bee Propolis: New Insights for Anticancer Drugs
}

\author{
Jaqueline Ferreira Campos $\mathbb{D}^{1}{ }^{1}$ Helder Freitas dos Santos $\mathbb{D},{ }^{1}$ Thaliny Bonamigo $\mathbb{D},{ }^{1}$ \\ Nelson Luís de Campos Domingues $\mathbb{D}^{2}{ }^{2}$ Kely de Picoli Souza $\mathbb{D}^{1}{ }^{1}$ \\ and Edson Lucas dos Santos $\mathbb{D}^{1}$ \\ ${ }^{1}$ Research Group on Biotechnology and Bioprospecting Applied to Metabolism (GEBBAM), Federal University of Grande Dourados, \\ Dourados, MS, Brazil \\ ${ }^{2}$ Organic Catalysis and Biocatalysis Laboratory (LACOB), Federal University of Grande Dourados, Dourados, MS, Brazil
}

Correspondence should be addressed to Jaqueline Ferreira Campos; jaquelinefcampos@ufgd.edu.br

Received 22 June 2021; Revised 16 August 2021; Accepted 3 September 2021; Published 23 September 2021

Academic Editor: Cinzia Domenicotti

\begin{abstract}
Copyright (c) 2021 Jaqueline Ferreira Campos et al. This is an open access article distributed under the Creative Commons Attribution License, which permits unrestricted use, distribution, and reproduction in any medium, provided the original work is properly cited.
\end{abstract}

\begin{abstract}
Natural products are important sources of biomolecules possessing antitumor activity and can be used as anticancer drug prototypes. The rich biodiversity of tropical and subtropical regions of the world provides considerable bioprospecting potential, including the potential of propolis produced by stingless bee species. Investigations of the potential of these products are extremely important, not only for providing a scientific basis for their use as adjuvants for existing drug therapies but also as a source of new and potent anticancer drugs. In this context, this article organizes the main studies describing the anticancer potential of propolis from different species of stingless bees with an emphasis on the chemical compounds, mechanisms of action, and cell death profiles. These mechanisms include apoptotic events; modulation of BAX, BAD, BCL2-L1 (BCL-2 like 1), and BCL-2; depolarization of the mitochondrial membrane; increased caspase-3 activity; poly (ADP-ribose) polymerase (PARP) cleavage; and cell death induction by necroptosis via receptor interacting protein kinase 1 (RIPK1) activation. Additionally, the correlation between compounds with antioxidant and anti-inflammatory potential is demonstrated that help in the prevention of cancer development. In summary, we highlight the important antitumor potential of propolis from stingless bees, but further preclinical and clinical trials are needed to explore the selectivity, efficacy, and safety of propolis.
\end{abstract}

\section{Introduction}

Cancer is among the main diseases affecting humanity, accounting for one in six deaths worldwide [1]. Many studies have been conducted to search for anticancer drugs that control and/or inhibit the proliferation of cancer cells. From 1946 to 2019,321 anticancer drugs were approved by the Food and Drug Administration (FDA), 168 (52.3\%) of which were related to natural products: 35 were of natural origin, 65 were derived from natural products, 45 were mimics of natural products, 22 had pharmacophores obtained from natural products, and one contained plant matter as an ingredient [2].

Some of the first anticancer drugs derived from natural products approved for clinical use include vincristine and vinblastine, which are both alkaloids obtained from Cathar- anthus roseus (L.) G. Don; camptothecin, an alkaloid obtained from Camptotheca acuminata Decne; and paclitaxel, a diterpene originally isolated from the bark of Taxus brevifolia Nutt., all of which are of plant origin $[3,4]$. These drugs are still used today, and the scientific literature details both the clinical importance of their uses [5-7] and their mechanisms of action $[8,9]$.

Additionally, other preclinical and clinical studies are being conducted with different drugs derived from phenolic compounds with anticancer potential, such as alvocidib, a synthetic flavonoid approved in phase 2 clinical studies for the treatment of different types of cancer, such as prostate cancer, pancreatic cancer, and leukemias; genistein, an isoflavonoid derived from soybean approved in phase 2 studies for the prevention and/or treatment of breast cancer and 
adenocarcinoma; and its synthetic derivative, idronoxil, which has been approved in phases 2 and 3 of clinical trials for the treatment of prostate and ovarian cancers, respectively [10].

Alkaloids, terpenes, and phenolic compounds are bioactive compounds with anticancer potential, are found mainly in plants, and are concentrated in microorganisms and metabolites of animal origin. In this context, research on the development of new anticancer drugs has not been limited only to plant substances or molecules. Researchers have investigated the anticancer potential of compounds produced by endophytic fungi [11], wasp venom peptides [12], and ant venom [13], as well as natural products from different bee species, such as honey $[14,15]$ and propolis $[16,17]$.

Among bee products, the propolis produced by the species Apis mellifera (Apidae, Apinae) has been extensively studied [18-20] as an antioxidant [21, 22], immunomodulatory agent $[23,24]$, and antimicrobial agent $[25,26]$ and mainly used in the prevention and treatment of cancer [17, 27-30]. In a search conducted on August 15, 2021, in the PubMed database of the NCBI (National Center for Biotechnology Information) using the terms "Apis propolis" and "Stingless Bee propolis," 719 studies were found on the bee propolis of $A$. mellifera, while only 86 studies involved propolis from stingless bees [31], also known as meliponines since they belong to the subfamily Meliponini of the family Apidae [32].

In the tropical and subtropical regions of the world, approximately 600 species of meliponines have been identified [33], most of which produce propolis in addition to other natural products with considerable bioprospecting potential. The anticancer potential of honey [15], cerumen [34], geopropolis [35], and propolis [16, 36, 37] produced by stingless bees has been described in the literature.

The first studies of the chemical composition and biological potential of propolis from meliponines emerged in the 1990s [38, 39]. A few years later, Bankova et al. [40] and Bankova and Popova [41] published two reviews on promising natural product. Recently, Lavinas et al. [42] published a review on the antioxidant, antimicrobial, and toxic activities of propolis from several species of stingless bees found in Brazil, and Popova et al. [43] highlighted the advances related to the chemical composition and biological activities of propolis of species found in the Americas, Asia, and Australia.

Studies developed in the last 30 years describe different mechanisms of action for this natural product and provide data on its safety, which may guide future studies and perspectives. This review highlights the importance of propolis from stingless bees as a promising natural resource for the development of new antitumor drugs and introduces new possibilities from a comparative perspective regarding the chemical substances described in propolis extracts, cell death profiles, and mechanisms of action.

\section{Propolis: Therapeutic Potential}

Propolis is a resinous material produced by bees using plant sources, such as exudates from leaves, stems, and flowers, mixed with wax and mandibular secretions [44, 45]. This material is used by bees to protect the hive from physical and biological factors. Propolis is deposited at the entrance of the nest and in external cracks to prevent invasion by other organisms, on the inside walls of the hive to maintain the appropriate internal temperature, and at the egg-laying site to maintain asepsis and is used to embalm dead organisms inside the nest, preventing the proliferation of microorganisms [46].

For centuries, humans have identified the importance of this product for bees and correlated its use with human health. Egyptians used propolis for its antiputrefactive properties to embalm the dead; Greeks and Romans used propolis as antiseptic and healing agent; Incas used propolis as an antipyretic agent, and in the 17 th century, propolis was listed as an official drug in the London Pharmacopoeia [47, 48].

During World War II (1939-1945), propolis was widely used as a healing agent and was prescribed by doctors to wounded soldiers [49]. This natural product gained popularity in Europe between the 17th and 20th centuries and was accepted in human and veterinary medicine in 1969 in the Soviet Union (USSR) for several applications, including the treatment of tuberculosis [45].

In 1985, propolis was recognized as a promising product in pharmacology in Japan [45]. Currently, the Japanese population highly values the benefits of this bee product and is even one of the largest importers of raw material produced in Brazil [48].

In recent decades, scientific publications on the chemical composition and biological properties of propolis from different bee species and different geographic origins have significantly increased. Propolis produced by stingless bees possesses antimicrobial $[50,51]$, antioxidant $[52,53]$, antiinflammatory $[54,55]$, and antitumor $[16,36,56,57]$ properties, among others.

The medicinal properties of propolis are directly related to its chemical composition. Studies conducted with propolis from stingless bees describe the presence of phenolic acids, aromatic acids, terpenes, carbohydrates [53, 58, 59], and alkaloids [16, 57]. The bee species and the botanical source from which they collect resin are among the factors responsible for the physical, chemical, and biological characteristics of this natural product $[52,60]$.

\section{Compounds with Antitumor Potential}

The diversity of the types of propolis produced by bees from tropical and subtropical regions results from the mixture of different compounds of plant and bee origin. In general, propolis is composed of approximately 50\% resin, 30\% wax, $10 \%$ essential oils, $5 \%$ pollen, and $5 \%$ other substances, including phenolic compounds, terpenes, aromatic aldehydes, alcohols, fatty acids, and minerals [61].

The genera of stingless bees most studied to determine the chemical composition and biological activities of propolis include Melipona, Plebeia, Trigona, Scaptotrigona, Trigonisca, and Tetragonisca [41, 42]. Bankova and Popova [41] report that the main chemical constituents present in propolis produced by different species of meliponines are 
terpenes, especially di- and triterpenes, in addition to phenolic acids and sugars. Sanches et al. [60] emphasize that stingless bees are attracted to terpenes and enrich propolis with raw material rich in these compounds.

Terpenes are compounds commonly found in different types of propolis, and several studies have shown their anticancer potential $[62,63]$. The mechanisms of action evidenced for these compounds include the modulation of the p53, peroxisome proliferator-activated receptor gamma $(\operatorname{PPAR} \gamma)$, mitogen-activated protein kinase (MAPK), nuclear factor $-\kappa \mathrm{B}(\mathrm{NF}-\kappa \mathrm{B})$, phosphoinositide 3-kinase $(\mathrm{PI} 3 \mathrm{~K}) /$ protein kinase $\mathrm{B}(\mathrm{AKT})$, and signal transducer and activator of transcription 3 (STAT3) signaling pathways and disruption of microtubules in the mitotic spindle, the latter of which is the main mechanism underlying the cytotoxic action of paclitaxel, one of the most successful commercially available terpenes [64].

In India, when investigating the composition of propolis produced by Trigona sp., Choudhari et al. [51] identified the presence of 24 compounds, including terpenes, alkanes, thiophilic acids, aromatic acids, aliphatic acids, sugars, and esters. Studies conducted with propolis from different bee species found in the Cerrado biome in the Central-West region of Brazil reported the presence of different proportions of terpenes, phenolic compounds, aromatic acids, and sugars in the ethanolic extracts of propolis from Melipona orbignyi [58] and Tetragonisca fiebrigi [55], which can directly influence the biological activities investigated.

When comparing the propolis of Melipona quadrifasciata anthidioides and Scaptotrigona depilis, Bonamigo et al. [36] observed that both extracts contain terpenes, phytosterols, tocopherol, and phenolic compounds at different concentrations and noted that only the extract of $M . q$. anthidioides, which showed the best cytotoxic action, contains the phenolic compounds vanillic acid, caffeic acid, quercetin, luteolin, and apigenin in its composition.

Globally, Brazil leads other countries in the number of studies assessing the chemical composition and biological activities of propolis from different species of stingless bees [42]. The country has substantial biodiversity, which contributes to the complexity of the types of this bee product. In southern Brazil, Cisilotto et al. [57] showed the unusual presence of piperidine alkaloids in the propolis extract of Scaptotrigona bipunctata, and in the Philippines, Desamero et al. [16] highlighted that the propolis of the species Tetragonula biroi contains more than 500 chemical constituents; approximately 15 of these compounds are promising candidates with anticancer activity according to chemical structure analyses and previous reports in the literature, including phenolic compounds (cinnamic acid and pterostilbene), terpenoids ( $\beta$-eudesmol), and alkaloids (colchicine), represented in Figure 1.

Colchicine has anticancer effects, induces caspase 3mediated apoptosis via suppressing the PI3K/Akt/mTOR signaling pathway on human gastric cancer cell lines, and suppresses the tumor growth in vivo [65]. Alkaloids are molecules widely known to have antitumor potential, and their main mechanisms of action include inhibition of the polymerization of microtubules that bind to $\beta$-tubulin subunits, inhibition of protein synthesis, and blockade of cell cycle progression, resulting in cell death by apoptosis [8].

Among the phenolic compounds, cinnamic acid was also found in propolis from Tetragonisca fiebrigi [55] and is considered one of the most potent antitumors, besides acting in the biosynthetic route of phenolic acids, such as caffeic acid (Figure 1), that acts on cell cycle modulation, inhibition of colony formation, and proapoptotic properties in cancer cells [66]. Pterostilbene, the 3,5-dimethoxy motif at the Aphenyl ring of resveratrol, has presented chemopreventive and chemotherapeutic properties in breast, prostate, and colon cancer cells, by inducing apoptotic and autophagic pathways, regulating the expression of metastasis-related proteins [67].

\section{Cytotoxic Potential of Propolis against Cancer Cell Lines}

The anticancer activity of an extract, fraction, or compound is evaluated in vitro and is initially investigated through the culture of cancer cell lines exposed to the material under study. Propolis from various species of stingless bees from different regions of the world has shown significant anticancer activity in different cell lines, as summarized chronologically in Table 1 .

Among the various species, the propolis from the species M. orbignyi, T. fiebrigi, S. depilis, M. q. anthidioides, and Plebeia droryana, which are found in Brazil, exhibited anticancer potential in human chronic myeloid leukemia K562 cells [36, $55,58,77]$. Propolis from the species S. bipunctata and M. $q$. anthidioides from southern Brazil, state of Santa Catarina, promoted cytotoxicity and inhibited migration and invasion in the human melanoma cell model SK-MEL-28 [57].

In Thailand, Umthong et al. [68] reported the antiproliferative activity of Trigona laeviceps propolis against five human cancer cell lines, namely, ductal carcinoma (BT474), colon adenocarcinoma (SW620), liver cancer (HepG2), lung cancer (ChaGo), and gastric cancer (KATO-III). Utispan et al. [37] also documented the cytotoxic action of propolis from the species Trigona sirindhornae in head and neck cancer cells (HN30). Additionally, propolis from the stingless bees Tetragonula pagdeni, Lepidotrigona ventralis, and Lepidotrigona terminata induced death in four human cancer cell lines, including colorectal cancer (Caco-2), liver cancer (Hep-G2), melanoma (SKMEL-28), and papilloma carcinoma KB cells [78].

In Indonesia, Kustiawan et al. [69] found that ductal carcinoma (BT474), colon adenocarcinoma (SW620), liver cancer (HepG2), lung cancer (ChaGo), and gastric cancer (KATO-III) cell lines were susceptible to the cytotoxic action of propolis from the species Timia apicalis, Trigona fuscobalteata, Trigona fuscibasis, and Trigona incisa. In another study, Kustiawan et al. [71] showed that propolis from the species $T$. incisa also exerts an antiproliferative effect on colon adenocarcinoma cells (SW620). Iqbal et al. [74] showed the cytotoxic action of propolis from Trigona spp. in a breast cancer cell line (MDA-MB-231) and documented its antiangiogenic action, while Amalia et al. [75] reported 
<smiles>O=C(O)/C=C/c1ccccc1</smiles>

Cinnamic acid<smiles>COc1ccc2c(c1OC)-c1ccc(OC)c(=O)cc1[C@@H](NC(C)=O)CC2</smiles>

Colchicine<smiles>Oc1ccc(/C=C/c2cc(O)cc(O)c2)cc1</smiles>

Pterostilbene<smiles>C=C1CCC[C@]2(C)CC[C@@H](C(C)(C)O)C[C@H]12</smiles>

$\beta$-eudesmol<smiles>O=C(O)/C=C/c1ccc(O)c(O)c1</smiles>

Caffeic acid

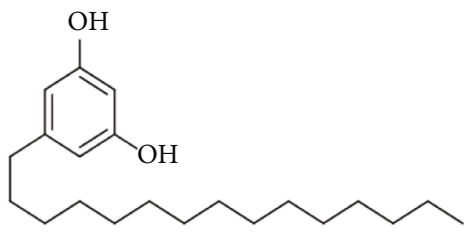

Cardol

FIGURE 1: Compounds found in propolis extracts from stingless bees that are promising for the development of antitumor drugs.

the antiproliferative activity of Trigona spp. in the MCF-7 breast cancer line.

In Vietnam, the cytotoxic potential of Trigona minor propolis was confirmed in a pancreatic cancer cell line (PANC-1) [72]. Propolis from species of the genus Trigona, which are common in India, was cytotoxic to breast cancer (MCF-7), colon adenocarcinoma (HT-29), colorectal adenocarcinoma (Caco-2), and murine melanoma (B16F1) cells [56]. Kothai and Jayanthi [70] revealed the cytotoxicity of propolis from the species Tetragonula iridipennis toward lung cancer cells (A549). In Malaysia, Mohd-Yazid et al. [73] reported that the propolis of the species Heterotrigona itama, which was collected at different locations, exerted a moderate cytotoxic effect on cervical carcinoma cells (HeLa), and Mohamed et al. [76] showed that the propolis extract of Tetrigona apicalis was toxic to breast cancer cells (MCF-7). Additionally, in the Philippines, propolis of the species $T$. biroi decreased the proliferation of four human gastric cancer lines (SFA, MKN-45, NUGC-4, and MKN-74) [16].

\section{Mechanisms of Cell Death Induced by Propolis}

Several cell death mechanisms have been identified based on morphological and molecular parameters, including apoptosis and necrosis [79], which are common mechanisms stimulated by propolis extracts from stingless bees. Apoptosis is a regulated mechanism of cell death performed in a safe and controlled manner by cells [17]. In this process, cells undergo rapid structural and biochemical changes, including nuclear chromatin condensation, cytoplasmic shrinkage, nuclear fragmentation, and the formation of plasma membrane blebs [80, 81]. Finally, the cell decomposes into apoptotic bodies, which are recognized and engulfed by phagocytes [82].

In contrast, necrosis is an energy-independent mechanism in which the cell suffers severe damage caused by a sudden shock, such as exposure to high temperatures, radia- tion, hypoxia, mechanical damage, and chemical substances, leading to the loss of its functions $[83,84]$. During this accidental and unregulated process, cell swelling, rupture of the membranes of the cellular organelles, chromatin digestion, DNA hydrolysis, and cell lysis occur [79]. Rupture of the plasma membrane and extravasation of the cell contents trigger inflammatory cascades [84].

In cases of an absence or unavailability of phagocytes during apoptosis, the process of secondary necrosis may be triggered $[85,86]$, which is also known as late apoptosis [87]. In addition, for two decades, this type of death was considered an accidental and unregulated process triggered by physicochemical injuries $[88,89]$. However, the mechanisms of a regulated form of necrosis, known as necroptosis, have already been described in the literature [90].

Necroptosis is a metabolically active form of regulated cell death resulting in a necrotic morphology [91] characterized by organelle swelling, loss of integrity, and rupture of the plasma membrane [92]. Similar to apoptosis, necroptosis can be induced by cell death receptors, such as tumor necrosis factor receptor (TNFR), and external and internal viral stimuli recognized by Toll-like receptors under conditions of caspase 8 inhibition [93].

Tumor necrosis factor receptor (TNFR) stimulation accompanied by caspase 8 inactivity activates receptor interacting protein kinase 1 (RIPK1) (RIPK1), which phosphorylates RIPK3 and leads to the formation of a signaling complex known as a necrosome [94-96]. Once activated, RIPK3 recruits and phosphorylates mixed lineage kinase domain-like pseudokinase (MLKL), which translocates to the plasma membrane and promotes cell lysis [93]. Studies have shown that MLKL leads to membrane disruption through the influx of calcium ions [97]. Reactive oxygen species (ROS) may also be involved and contribute to the necroptosis process [98].

The discovery of necroptosis as an alternative form of programmed cell death is advantageous in the treatment of 


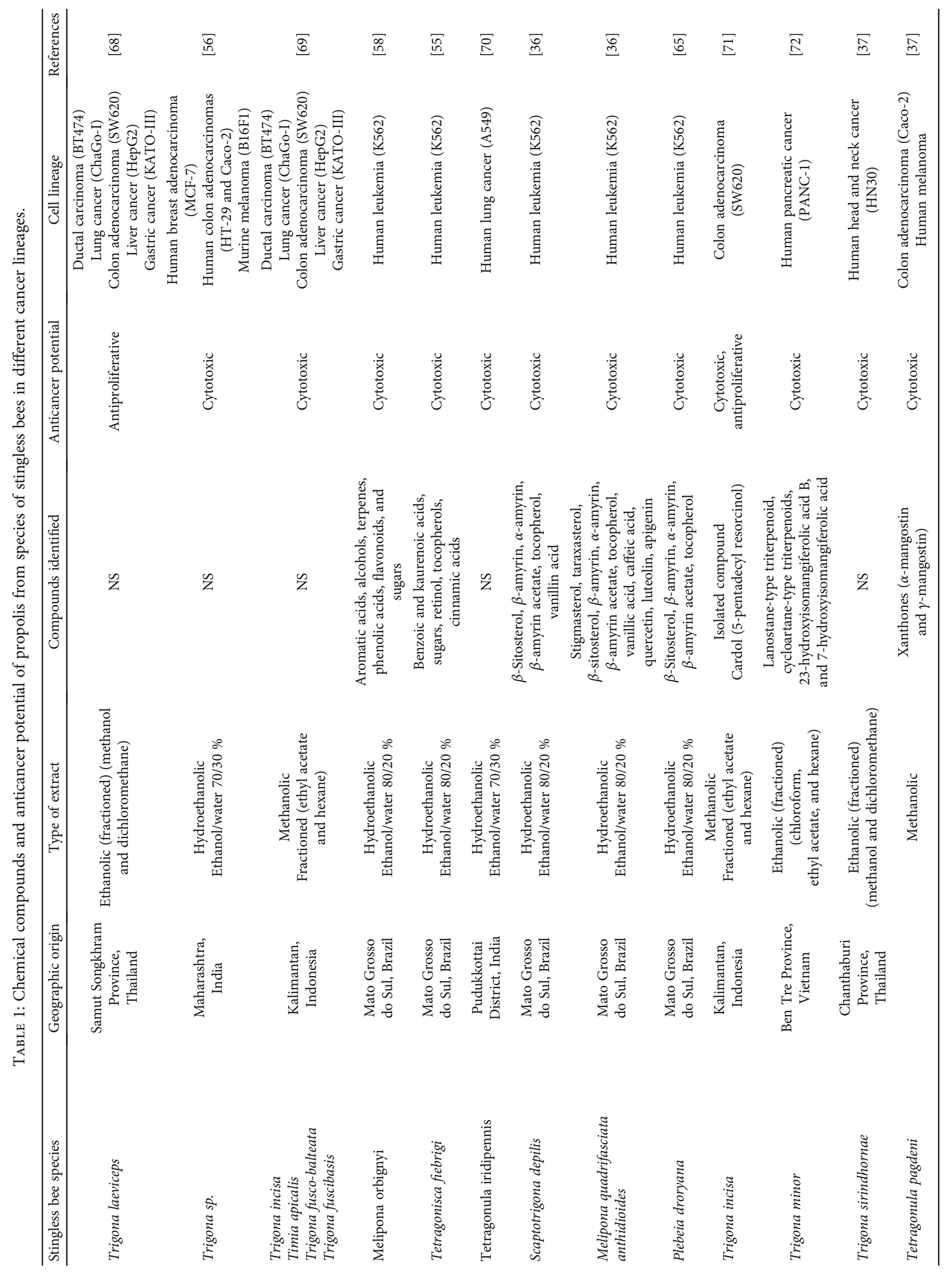




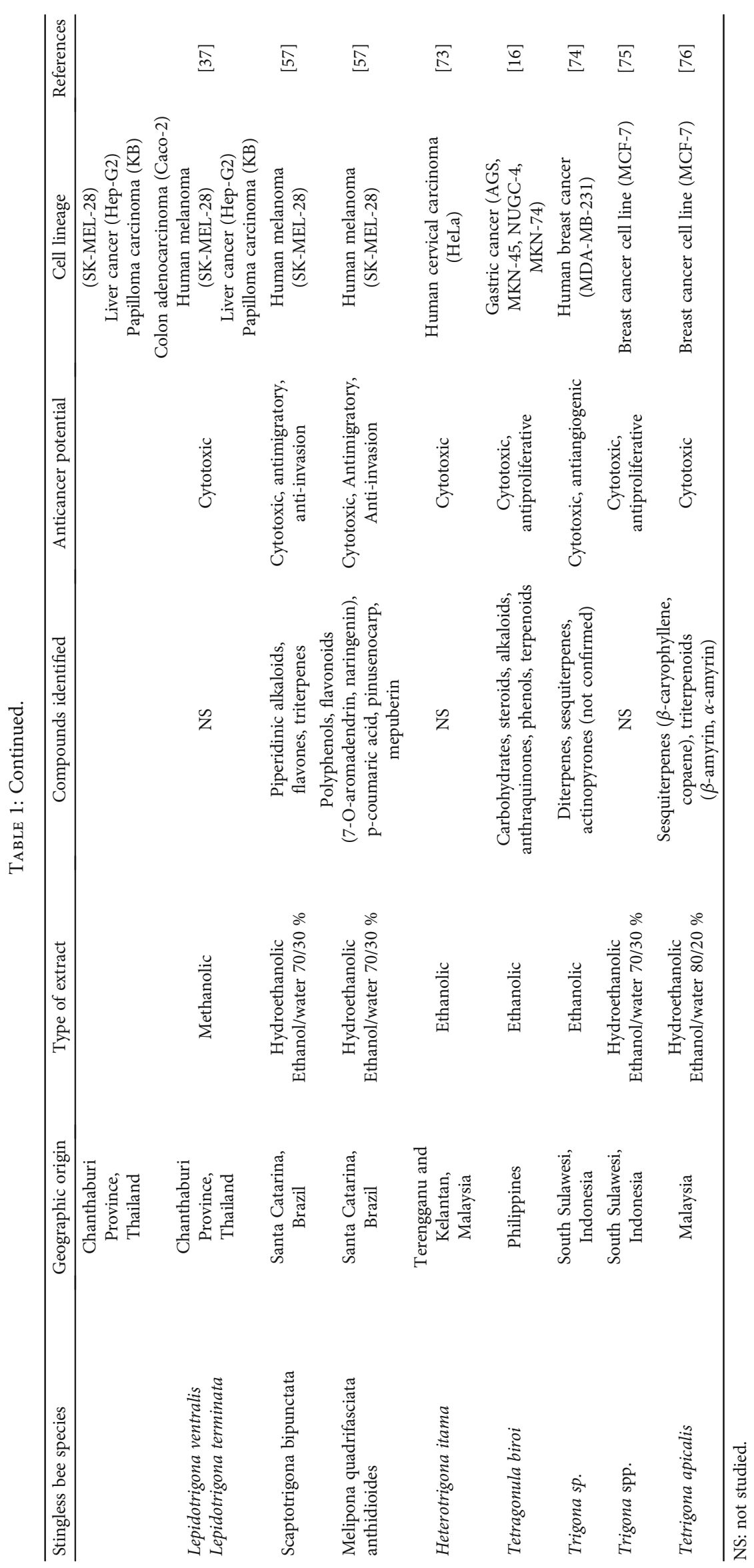


cancer because it involves a highly specialized pathway, enabling specific targeting by drugs [99]. In the human body, programmed cell death (apoptosis) has the physiological role of eliminating abnormal or harmful cells and serves as the main mechanism of tumor suppression. In most cancers, dysregulation of different molecules controls this event [17], which hinders cell death. The main objective of an anticancer agent is to reverse this process, thus eliminating tumor cells. Studies with propolis from different species of stingless bees have reported its ability to induce necrosis and apoptosis in different cancer cell lines (Table 2).

In Brazil, propolis from the species M. orbignyi, T. fiebrigi, S. depilis, and $M$. q. anthidioides showed similar cell death profiles and was able to promote cell death by necrosis and late apoptosis in K562 cells (human leukemia) [36, 55, 58]. In addition, Bonamigo et al. [77] preincubated K562 cells with the necroptosis inhibitor necrostatin-1 (NEC-1), followed by treatment with $P$. droryana propolis, and observed a reversal of cell death, confirming that the mechanism of death was mediated by necroptosis, a form of regulated necrosis.

In Indonesia, Kustiawan et al. [100] observed that the fractionated propolis extract from $T$. incisa promoted cell death by apoptosis of SW620 cells after 2-6h of treatment, and after $24-72 \mathrm{~h}$, death by inducing the necrosis was observed. When they isolated the compound cardol (5-pentadecylresorcinol) from this extract, Kustiawan et al. [71] confirmed the apoptotic death of the same cell line. The chemical structure of the cardol is represented in Figure 1.

In comparison, the propolis extract of the species $H$. itama found in Malaysia [73] and the species S. bipunctata and M. q. anthidioides found in southern Brazil [57] promoted death by apoptosis in HeLa and human melanoma cells (SK-MEL-28), respectively. In a more recent study conducted by Desamero et al. [16], apoptotic death was also induced by propolis from the species T. biroi, which is found in the Philippines, in the gastric cancer lines (SFA, MKN-45, and NUGC-4). The types of cell death triggered by different propolis extracts from stingless bees are outlined in Figure 2 to better understand and visualize this information.

\section{Effects of Propolis on the Activation of Apoptotic Pathways}

Cell death by apoptosis is activated by the extrinsic pathway through death receptors present on the cell surface or the intrinsic pathway through damage to the mitochondria [101]. The extrinsic pathway is initiated through the interaction of ligands of immune cells with programmed death receptors, such as TNF receptor 1 (TNFR1), CD95 (also known as Fas and APO-1), Death receptor 3 (DR3), and TNF-related apoptosis-inducing ligand receptor 1 (TRAILR1), also known as Death receptor 4 or DR4, while the intrinsic or mitochondrial pathway is triggered by cytotoxic stimuli such as radiation, hypoxia, and DNA damage [84].

Initially, intracellular proteolytic enzymes, known as caspases, which are classified into initiators and effectors, are activated in this cell death pathway [83]. Regarding the extrinsic and intrinsic pathways, the initiator caspases are 8 and 9, respectively [84]. After the activation of caspase 8 or 9 , both pathways promote the cleavage and activation of effector caspase 3, resulting in cascades of fragmentation and degradation of DNA and proteins and the formation of apoptotic bodies [102]. Thus, the extrinsic and intrinsic pathways are not completely independent of each other; they converge in the activation of caspases during the signaling cascade, promoting the formation of apoptotic bodies and their engulfment by phagocytosis [103].

Some authors have investigated the role of propolis in inducing apoptotic cell death in more detail (Table 2). In a study conducted by Bonamigo et al. [77], in addition to propolis from the species $P$. droryana mainly inducing death by necroptosis, the extract also promoted death by apoptosis, as evidenced by an increase in caspase 3 cleavage and activation in K562 human leukemia cells.

Other molecular targets related to apoptotic pathways can be studied, including initiator caspases. The intrinsic pathway, for example, is controlled by three structurally distinct groups of the BCL protein family: (I) BH3 proteins, which are stimulators; i.e., they transmit signals for the onset of apoptosis; (II) BLC-2 proteins, which promote antiapoptotic action, thus ensuring cell survival; and (III) proapoptotic effector proteins BAX and BAK [82].

The propolis of the bee species found in Brazil, S. bipunctata and M. q. anthidioides, promoted a decrease in the expression levels of the antiapoptotic protein BCL-2, an increase in ROS production, and depolarization of the mitochondrial membrane, leading to cell death by apoptosis through the modulation of the intrinsic pathway [57]. Similarly, Desamero et al. [16] observed that propolis of the species $T$. biro i induces apoptosis by modulating the transcript levels of genes related to the expression of proteins associated with apoptosis. The study revealed a considerable reduction in the expression of the antiapoptotic genes BCL2L1 and BCL-2 and overexpression of the proapoptotic genes BAX and BAD.

The compound cardol isolated from the propolis of $T$. incisa also induces the death of SW620 cells via apoptosis through the activation of the mitochondrial pathway as evidenced by the increased expression of the active forms of caspases 9 and 3, poly (ADP-ribose) polymerase (PARP) cleavage, and depolarization of the mitochondrial membrane [71]. The authors also showed that cardol stimulated an increase in ROS levels, a common mechanism of the intrinsic apoptosis pathway, and cell death was partially reversed in the presence of the inhibitor $\mathrm{N}$-acetyl-L-cysteine (NAC). The mechanisms underlying the cytotoxicity of the propolis extracts are shown in Figure 2.

\section{Effects of Propolis on the Cell Cycle of Cancer Cell Lines}

In addition to the loss of death mechanisms, cancer cells also undergo deregulation of their cell cycle, resulting in increased cell proliferation. In general, to proliferate, cells duplicate their contents and subsequently enter division in a process called the cell cycle [104]. 


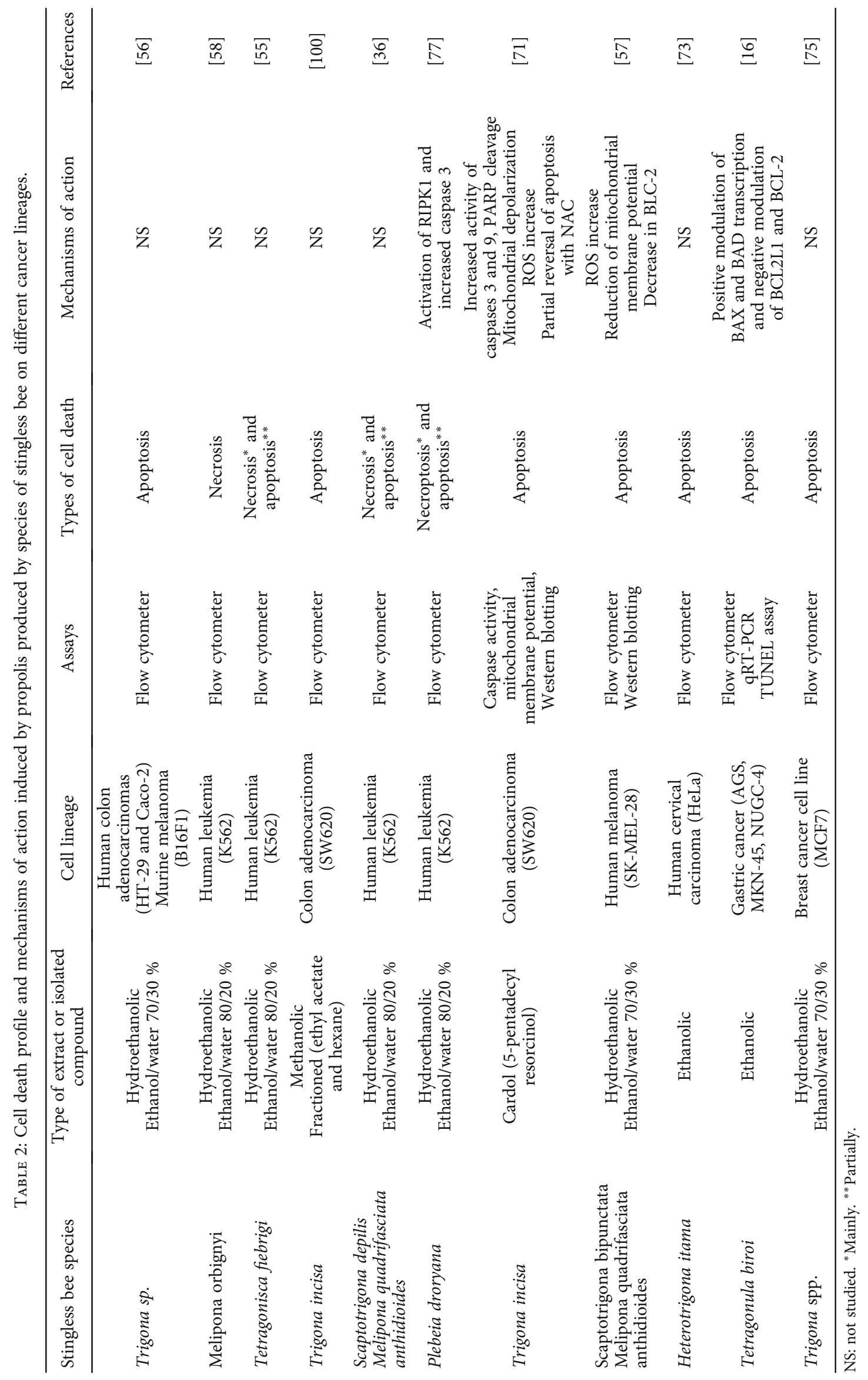




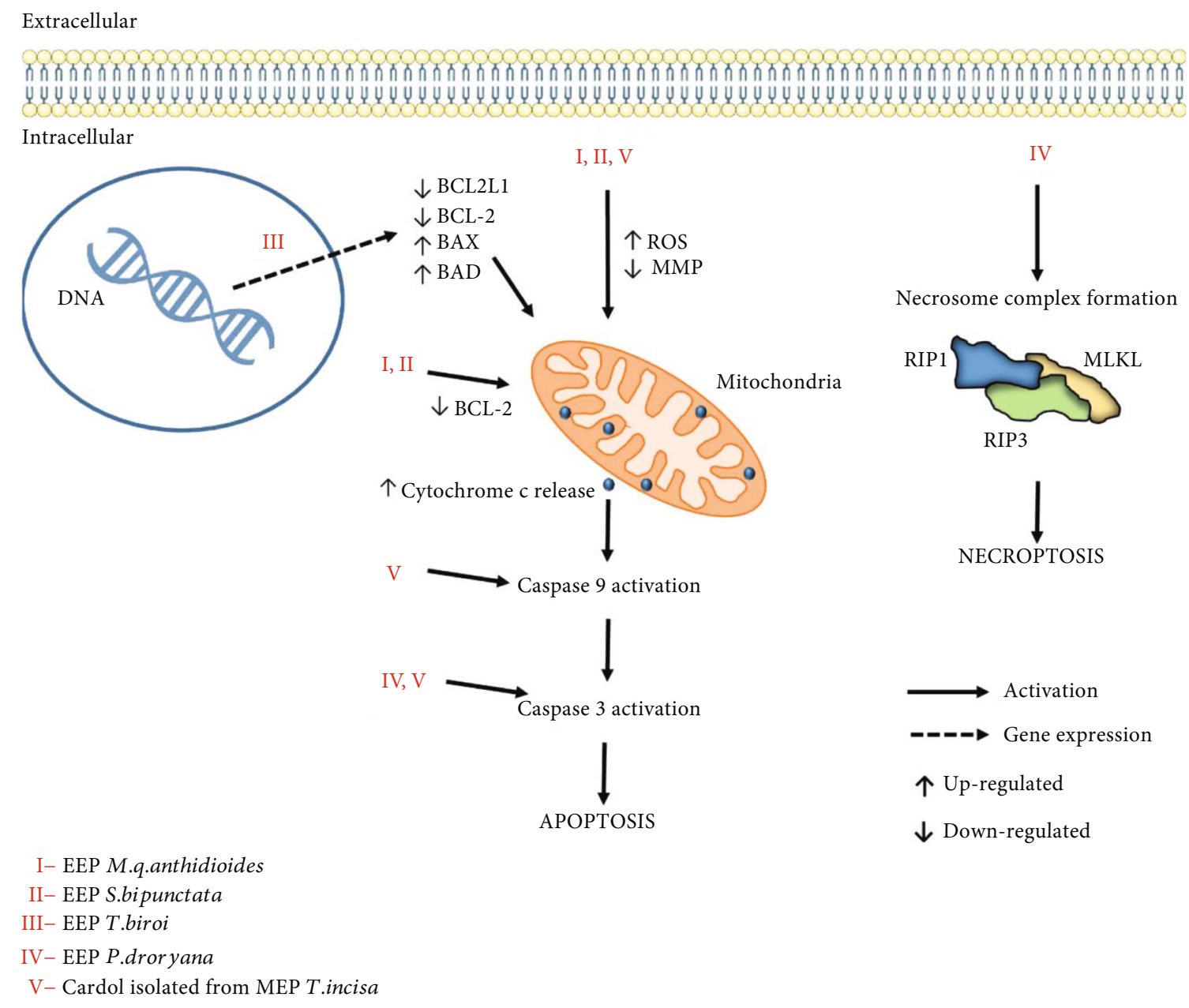

Figure 2: Cell death mechanisms induced by the extracts and/or compounds isolated from propolis from stingless bees.

Basically, the progression of this cycle is linked to specific phases that occur in the interphase and mitosis periods [105]. After leaving the G0 phase (quiescence), the cells enter interphase, which is sequentially divided into G1 (cell growth), S (DNA synthesis), and G2 (preparation for mitosis) phases, and then, the mitosis period or $\mathrm{M}$ phase, where the equal distribution of genetic material and cytokinesis, occurs $[17,106,107]$.

The progression of the cell cycle is regulated by the joint action of cyclin-dependent kinases (CDKs) and proteins that control their activation and substrate specificity, which are called cyclins [108]. As members of a serine/threonine kinase family, CDKs are enzymatically active and participate in the following processes: (I) interaction with cyclins to form active heterodimeric complexes and (II) phosphorylation of threonine residues present in their activation segment $[105,109]$.

In mammals, the main CDKs involved in the cell cycle are CDK1, CDK2, CDK4, and CDK6, which form active enzyme complexes with specific cyclins: CDK1 with cyclins $\mathrm{A} / \mathrm{B}, \mathrm{CDK} 2$ with cyclins $\mathrm{A} / \mathrm{E}$, and $\mathrm{CDK} 4 / 6$ with cyclin $\mathrm{D}$ [110]. CDKs 4/6 and cyclin D act in G1-S phases of the cell cycle, preparing cells for the $S$ phase, where CDK 2 and cyclins A/E participate at its onset and progression, while
CDK 1 and cyclins A/B mediate the S-G2 and G2-M transitions $[109,111]$.

The activity of CDKs that contribute to advancement of the cell cycle is induced by mitogenic signals and inhibited by activation of cell cycle checkpoints, which respond to genetic integrity failures $[107,112]$. In addition, the progression of the cell cycle is blocked by the tumor-suppressive action of retinoblastoma (pRb) and p53 proteins $[105,113]$ and the action of endogenous inhibitors of cyclindependent kinases (CKIs), which control CDK activity [114].

Humans express two families of CKIs: the lnk family (p15, p16, p18, and p19), which binds to CDKs $4 / 6$ and prevents their interaction and activation by cyclin $\mathrm{D}$, and the Cip/kip family (p21, p27, and p57), which interrupts and inactivates $\mathrm{CDK} /$ cyclin complexes, such as CDK2/cyclin A or $\mathrm{E}$ and $\mathrm{CDK} 1 /$ cyclin A or B [114-116]. In general, CKIs promote cell cycle arrest [105] and play a critical role in cell cycle regulation [117]. Thus, before returning to the division process, possible damage to the genetic material can be repaired, or severely damaged cells are eliminated via apoptosis $[115,118]$.

The cell cycle is a highly regulated and ordered process due to rigorous cooperation between CDKs, cyclins, and 
TABLE 3: In vitro effects of propolis from different stingless bee species on the cell cycle of cancer lineages.

\begin{tabular}{|c|c|c|c|c|c|c|c|}
\hline $\begin{array}{l}\text { Stingless } \\
\text { bee species }\end{array}$ & $\begin{array}{l}\text { Region/ } \\
\text { country }\end{array}$ & $\begin{array}{l}\text { Extract type } \\
\text { or isolated } \\
\text { compound }\end{array}$ & Cell lineage & Assays & $\begin{array}{l}\text { Effects on } \\
\text { cell cycle }\end{array}$ & $\begin{array}{c}\text { Involved } \\
\text { mechanisms }\end{array}$ & References \\
\hline Trigona incisa & $\begin{array}{l}\text { Kalimantan, } \\
\text { Indonesia }\end{array}$ & $\begin{array}{l}\text { Methanolic } \\
\text { Fractioned } \\
\text { (ethyl acetate } \\
\text { and hexane) }\end{array}$ & $\begin{array}{c}\text { Colon } \\
\text { adenocarcinoma } \\
(\text { SW620 })\end{array}$ & $\begin{array}{c}\text { Flow } \\
\text { cytometer }\end{array}$ & $\begin{array}{c}\text { Cell cycle arrest } \\
\text { (G1 phase) }\end{array}$ & NS & {$[100]$} \\
\hline $\begin{array}{l}\text { Melipona } \\
\text { quadrifasciata } \\
\text { anthidioides }\end{array}$ & $\begin{array}{c}\text { Santa } \\
\text { Catarina, } \\
\text { Brazil }\end{array}$ & $\begin{array}{c}\text { Hydroethanolic } \\
\text { Ethanol/water } \\
70 / 30 \%\end{array}$ & $\begin{array}{c}\text { Human } \\
\text { melanoma } \\
(\mathrm{SK}-\mathrm{MEL}-28)\end{array}$ & $\begin{array}{c}\text { Flow } \\
\text { cytometer }\end{array}$ & $\begin{array}{l}\text { Cell cycle arrest } \\
\text { (G2/M phases) }\end{array}$ & NS & [57] \\
\hline $\begin{array}{l}\text { Tetragonula } \\
\text { biroi }\end{array}$ & Philippines & Ethanolic & $\begin{array}{c}\text { Gastric cancer } \\
\text { (AGS, MKN-45, } \\
\text { NUGC-4) }\end{array}$ & $\begin{array}{c}\text { Flow } \\
\text { cytometer } \\
\text { qRT-PCR }\end{array}$ & $\begin{array}{l}\text { Cell cycle arrest } \\
\text { (G0/G1 phases) }\end{array}$ & $\begin{array}{l}\text { Positive modulation } \\
\text { of the transcription of } \\
\text { inhibitory genes of the } \\
\text { cell cycle (CDKN1A, } \\
\text { CDKN1B, tp53) and } \\
\text { negative modulation for } \\
\text { transcription of (CDK1, } \\
\text { CDK2, and CCND1) } \\
\text { related to kinases and } \\
\text { cyclins }\end{array}$ & {$[16]$} \\
\hline
\end{tabular}

NS: not studied.

CKIs [119]. However, in cancer cells, the levels of these proteins are often deregulated due to mutations and abnormal expression of cell cycle genes [105, 120]. These mutations inactivate CKIs and hyperactivate CDKs [118]. Upon the deactivation of its inhibitory mechanisms, the cell cycle and proliferation occur uncontrollably [105]. Thus, CDK inhibitors are an alternative treatment for cancer, and one of the focuses in related research is the development of drugs targeting the cell cycle and CDK transcription [121].

In recent decades, the action of various compounds derived from natural products in regulating the expression of proteins involved in cell cycle modulation has received considerable attention [122]. Recently, studies involving the propolis of some species of stingless bees have attracted attention given the promising effects of this natural product on cancer cells, as summarized in Table 3 and represented in Figure 3.

The propolis produced by $T$. incisa promotes cell cycle arrest in SW620 cells in the G1 phase [100], while the propolis produced by $M$. q. anthidioides induces cell cycle arrest in SKMEL-28 cells in the G2/M phase [57]. Desamero et al. [16] highlighted that the propolis of the species T. biroi arrests the cell cycle of gastric cancer cell lines in the G0/G1 phase through the positive modulation of the expression levels of genes encoding cell cycle inhibitor proteins, such as CDKN1A (CyclinDependent Kinase Inhibitor 1A) and CDKN1B (Cyclin-Dependent Kinase Inhibitor $1 B$ ) and a tumor suppression gene (TP53).

The TP53 gene encodes $\mathrm{p} 53$, a protein involved in DNA repair, cell cycle arrest, and apoptosis [123]. Compared to all other human genes, TP53 has the highest mutation rate [124]. Additionally, Desamero et al. [16] found that the ethanolic extract of $T$. biroi propolis downregulates the expression levels of the CDK1, CDK2, and CCND1 genes, which encode the CDK1, CDK2, and cyclin D1 proteins

In this context, as CDKs are usually hyperactivated in cancer, these molecules are one of the key targets for con- trolling the progression of this disease [125], highlighting the little-explored pharmacological potential of propolis from stingless bees.

\section{Effects of Propolis on Intracellular Signaling Pathways}

Intercellular communication is performed by small molecules (growth factors, hormones, cytokines, and neurotrophic factors) and other extracellular signaling molecules that interact with specialized "targets" (receptors) in the cell membrane, inducing a series of intracellular processes [126, 127]. Receptor tyrosine kinases (RTKs) function by activating and regulating signaling pathways related to various cellular processes, such as cell growth, proliferation, differentiation, survival, gene transcription, and metabolic regulation [128].

Several diseases result from genetic mutations or abnormalities that can alter the activity, quantity, cellular distribution, or regulation of RTKs; for example, mutations in these receptors and exacerbated activation of their signaling pathways have been associated with diabetes, inflammation, and cancer [129]. Signaling pathways such as RAS and PI3K can also be affected by mutations and contribute to the development of cancer in humans [130].

One of the most frequently altered pathways in human cancers is the PI3K signaling pathway [131]. Alterations include losses of lipid phosphatases (PTEN and INPP4B) and mutations in genes encoding (I) catalytic subunits (p110 $\alpha$ and $\mathrm{p} 110 \beta)$, (II) regulatory subunits (p85 $\alpha, \mathrm{p} 55 \alpha$, and p50 $\alpha$ ), (III) PI3K activator K-RAS, and (IV) AKT (effector protein of the PI3K pathway) and its isoforms (AKT1, AKT2, and AKT3) $[132,133]$. Total phosphorylation of AKT activates a multitude of downstream targets; through phosphorylation of its various substrates (mTOR, GSK3, NF- $\kappa$ B, MDM2, $\mathrm{BAD}$, and FKHR), AKT exerts signals that lead to cell growth 


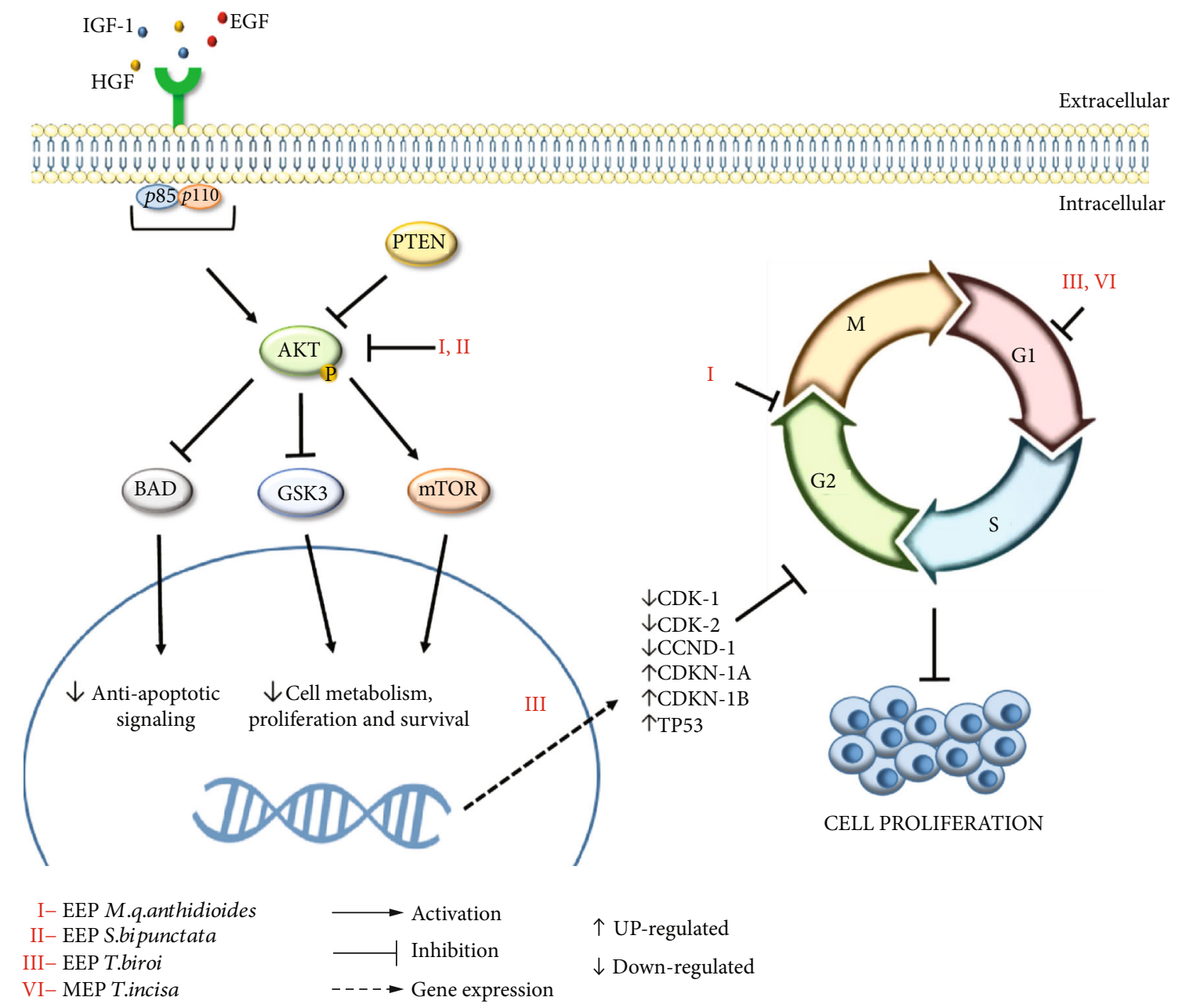

FIGURE 3: Modulation of the P13K/AKT signaling pathway and cell cycle arrest promoted by propolis extracts from stingless bees.

and differentiation, angiogenesis, and apoptosis inhibition $[130,134]$ and are related to the onset of metastases [135].

Several efforts have been made to develop effective therapies targeting PI3K/AKT signaling; however, current PI3K and AKT inhibitors have shown limited efficacy and restricted doses due to toxicity $[131,132]$. In this context, the search for new agents that can act on different signaling pathways, including PI3K/AKT, is key for the development of new therapies that can improve the quality of life of cancer patients.

Among the several studies on propolis from stingless bees with anticancer potential addressed in this review, only Cisilotto et al. [57] further investigated the effects of propolis from S. bipunctata and M. q. anthidioides on PI3K/AKT, a signaling pathway frequently altered in human cancers. They showed that the propolis of the two stingless bee species decreased the levels of protein expression, including one of the effector isoforms of the PI3K signaling pathway, as shown in Figure 3. The decreased signaling may be a mechanism related to other findings of the study, such as decreased levels of BCL-2 proteins, cell death by apoptosis, and decreased migration and invasion of human melanoma cells (SK-MEL-28).

\section{Antioxidant and Anti-inflammatory Activities of Propolis: Chemopreventive Potential}

Several pathophysiological conditions are directly related to the development of different types of cancer, including oxidative stress, chronic inflammation, and prolonged exposure to mutagens. Propolis from stingless bees has considerable potential to prevent deleterious changes in cellular metabolism since its antioxidant, anti-inflammatory, and immunomodulatory potential has already been described [42, 43, 60].

Antioxidant substances can inhibit and/or reduce the damage caused by reactive species by minimizing their reaction with biomolecules, such as proteins, lipids, and nucleic acids [136]. At normal physiological levels, reactive oxygen species (ROS) or reactive nitrogen species (RNS) play vital functions during cellular respiration, phagocytosis, inflammation, platelet aggregation, and angiogenesis [137]. However, excess radical species in the body, especially hydroxyl $\mathrm{OH}$ radicals, are related to the activation of different oncogenes or mutations of tumor suppression genes, which are important steps in the development of cancer [138]. 
The relationship between reactive species and chronic inflammatory processes is directly related to carcinogenesis: (I) high ROS concentrations alter membrane permeability, modify proteins, decrease the catalytic activity of enzymes, generate DNA damage, and consequently lead to genomic instability [139]; and (II) chronic inflammatory processes may play a critical role in cancer initiation, development, growth, and metastasis [140], since cytokines regulate cell proliferation, survival, differentiation, migration, and death [141].

Propolis from stingless bees has already been described as having antioxidant potential, acting in the direct scavenging of free radicals and the inhibition of lipid peroxidation $[36,58,77,142]$. Lipid peroxidation results from reactive species attacking lipids present in the cell plasma membrane, promoting the production of highly carcinogenic molecules in human cells, such as malondialdehyde, which leads to insertions, deletions, and substitutions of base pairs in DNA [143].

Lipid peroxidation in nontumor cells may also be due to inflammatory responses associated with the development and invasion of cancer [138]. The relationship between reactive species and chronic inflammatory processes is directly related to carcinogenesis; therefore, compounds that neutralize both deleterious effects of the tumor microenvironment are of great importance [144, 145]. Campos et al. [55] noted that in addition to acting as an antitumor agent in a leukemic cell line, the ethanolic extract of propolis of T. fiebrigi has antioxidant activity by inhibiting lipid peroxidation in human erythrocytes and anti-inflammatory activity by inhibiting hyaluronidase. Similarly, Massaro et al. [54] demonstrated that propolis of the Australian species Tetragonula carbonaria inhibits the activity of the enzyme 5lipoxygenase (5-LOX), which is known to catalyze the production of proinflammatory mediators. In addition, polar extracts of $T$. carbonaria propolis have been described to have antioxidant properties and to suppress production of the proinflammatory eicosanoid leukotriene B4 in human neutrophils stimulated with ionomycin [146].

Substances found in propolis of stingless bees, such as quercetin and apigenin, promote downregulation of tolllike receptor 4 (TLR4) and a decline in protein levels of AP-1 (key transcription factor which regulates several cytological processes, including proliferation, apoptosis, and cell migration) and together with the increase in the sirtuin 1(Sirt1)/Nrf2 pathway induce antioxidant defenses and reduce inflammation and oxidative stress [147].

\section{Selectivity and Safety of Propolis Use}

Despite the benefits promoted by drugs in controlling cancer cell proliferation, chemotherapy drugs have important side effects, such as fatigue, diarrhea, nausea, hair loss, cardiovascular and renal complications, and chronic effects such as infertility [148]. Thus, the search for compounds or molecules that have antitumor selectivity and minimal side effects is encouraged. Studies show that propolis from different species of stingless bees has selectivity against tumor cell lines, resulting in higher cytotoxicity than that observed in nontumor lines $[68,100]$.

Bonamigo et al. [77] found that the ethanolic extract of propolis of Plebeia droryana promotes lower cytotoxicity against human peripheral blood mononuclear cells than K562 cells. The erythroleukemic cell line K562 is described for its resistance to apoptotic death [149]; therefore, other types of death, such as necrosis or necroptosis, are necessary to inhibit the proliferation of these tumor cells [83]. Propolis of the species found in the Central-West region of Brazil, including $M$. orbignyi [58], T. fiebrigi [55], S. depilis, and M. q. anthidioides [36], also promotes the death of this leukemic cell line that is resistant to conventional chemotherapeutic agents.

In a study by Cisilotto et al. [57], when evaluating the cytotoxicity of S. bipunctata and $M . q$. anthidioides in a human melanoma cell line (SK-MEL-28) and a human melanocyte nontumor cell line (NGM), the authors found high selectivity for tumor cells. Additionally, these propolis extracts potentiated the action of the chemotherapeutic agent vemurafenib, which is used in cases of metastatic melanoma with mutations in the BRAF protooncogene. Mohamed et al. [76] investigated the selectivity of the cytotoxic action of the propolis extract of Tetrigona apicalis in a breast cancer cell line (MCF-7) and an epithelial breast nontumor cell line (MCF 10A) and found that after $72 \mathrm{~h}$ of incubation, the tumor cells were more sensitive to treatment.

In addition to evaluating selectivity in in vitro cell models, selectivity must also be assessed in multicellular in vivo models [42], which is a key step in the development of new drugs. From this perspective, 21 samples of propolis from Brazilian stingless bees were analyzed for toxicity in the microcrustacean Artemia salina, which demonstrated lethal doses in $50 \%$ of the individuals (LD50) ranging from $0.3 \pm$ 0.2 to $>1000 \mu \mathrm{g} / \mathrm{mL}$ [150].

Bonamigo et al. [36] investigated the activity of the ethanolic extract of propolis from S. depilis and M. q. anthidioides $(250-1000 \mu \mathrm{g} / \mathrm{mL})$ in the Caenorhabditis elegans animal model and observed no toxic or lethal effects after $24 \mathrm{~h}$ of incubation despite this extract showing effective antitumor activity. The nematode $C$. elegans has been widely used in toxicity studies of pharmacological compounds, including natural products $[151,152]$. C. elegans is an excellent in vivo model to complement cell culture assays, has a good correlation with the LD50 observed in rodents, and contains many genes and signaling pathways similar to those in humans [151].

However, studies on the toxicity or pharmacological potential of propolis from stingless bees in mammals are still scarce. Recently, Desamero et al. [16] investigated the antitumor potential of $T$. biroi propolis $(100 \mathrm{mg} / \mathrm{kg})$ in A4gntknockout (KO) mice (gastric adenocarcinoma model) and its effects on a C57BL/6 J model (wild-type). The authors demonstrated the efficacy of the extract on the regression of histological and macroscopic lesions of pyloric gastric tumors; in the control animal model, no differences were observed in the morphology or thickness of the gastric mucosa or T-lymphocyte infiltration between animals treated with distilled water or the ethanolic extract of $T$. biroi. 
As a means to complement in vitro and in vivo studies on the toxicity of propolis extracts and their compounds, Lavinas et al. [42] analyzed the potential toxicity of these products in silico using ADMET Predictor ${ }^{\text {TM }}$ software and found low toxicity, indicating that these compounds are potentially safe to use. Recent technological and scientific advances have contributed to the natural product-based drug discovery, such as tools that enable the analysis of genetic information, the prediction of chemical structures and pharmacological activities, and the integration of data sets with diverse information [153]

However, Lavinas et al. [42] emphasized the need for preclinical studies to demonstrate the efficacy of propolis in the development of future drugs. Recently, there are no clinical studies conducted with propolis of stingless bees; in addition, Chiu et al. [29] highlight that few clinical trials are conducted with propolis of the species $A$. mellifera and its active components, which present unsatisfactory results. The authors attribute the reduced efficacy of propolis in clinical trials to its low solubility in water and suggest the use of formulations in nanoparticles. Natural product-based nanoformulations have been proposed to solve problems such as the low solubility of these compounds in water, in addition to minimizing side effects of therapy against different types of cancers [154].

Khongkaew and Chaemsawang [155] evaluated the propolis of stingless bees in the formulation of nanoparticles and reported that it presents high physicochemical stability, besides not presenting toxicity in human fibroblast cells, and suggests future pharmaceutical applications.

\section{Conclusions and Perspectives}

Cancer is a highly complex disease in which alterations can occur in different genes, consequently altering multiple cells signaling pathways in different types of tumors. Most chemical treatments targeting cancer are not very selective and cause complications for patients and/or are very expensive. Therefore, research on natural products such as propolis is extremely relevant to identify new therapies that minimize side effects, increase the effectiveness of current treatments, and enable the development of new drugs with more effective mechanisms of action.

The scenario presented regarding the antitumor activity of propolis from stingless bees, as well as its mechanisms of action and induced cell death profile, demonstrates the substantial bioprospecting potential of this natural product. Given the diversity of stingless bee species distributed around the world, much remains to be investigated in the search for new prototypes for the development of anticancer drugs. However, with the accelerated loss of biodiversity due to anthropogenic activity, promoting the preservation of these species and their environments, as well as research on the antitumor activity of their bee products, is an urgent endeavor.

Newman and Cragg [2] emphasize that natural products are still the best sources for the discovery of novel agents/active templates and offer the potential to discover novel structures that can lead to effective agents in a variety of human diseases, including cancer. In summary, the chemical diversity and different mechanisms of cell death induced by propolis from stingless bees reflect the promising potential of this product for the development of new antitumor drugs, which should be expanded through further preclinical and clinical studies.

\section{Conflicts of Interest}

The authors declare that there are no conflicts of interest.

\section{Acknowledgments}

This work was supported by grants from Pró-Reitoria de Ensino de Pós-Graduação e Pesquisa da Universidade Federal da Grande Dourados (PROPP-UFGD); Fundação de Apoio ao Desenvolvimento do Ensino, Ciência e Tecnologia do Estado de Mato Grosso do Sul (FUNDECT); Coordenação de Aperfeiçoamento de Pessoal de Nível Superior (CAPES), Conselho Nacional de Desenvolvimento Científico e Tecnológico (CNPq); and Financiadora de Estudos e Projetos (Finep).

\section{References}

[1] WHO, Cancer, World Health Organization, 2018.

[2] D. J. Newman and G. M. Cragg, "Natural products as sources of new drugs over the nearly four decades from 01/1981 to 09/2019," Journal of Natural Products, vol. 83, no. 3, pp. 770-803, 2020.

[3] T. N. Chinembiri, L. du Plessis, M. Gerber, J. H. Hamman, and J. du Plessis, "Review of natural compounds for potential skin cancer treatment," Molecules, vol. 19, no. 8, pp. 1167911721, 2014.

[4] D. Tewari, P. Rawat, and P. K. Singh, "Adverse drug reactions of anticancer drugs derived from natural sources," Food and Chemical Toxicology, vol. 123, pp. 522-535, 2019.

[5] E. Martino, S. Della Volpe, E. Terribile et al., "The long story of camptothecin: from traditional medicine to drugs," Bioorganic \& Medicinal Chemistry Letters, vol. 27, no. 4, pp. 701707, 2017.

[6] S. Ezrahi, A. Aserin, and N. Garti, "Basic principles of drug delivery systems - the case of paclitaxel," Advances in Colloid and Interface Science, vol. 263, pp. 95-130, 2019.

[7] Y. Qu, O. Safonova, and V. De Luca, "Completion of the canonical pathway for assembly of anticancer drugs vincristine/vinblastine in Catharanthus roseus," Plant Journal, vol. 97, no. 2, pp. 257-266, 2019.

[8] T. Isah, "Anticancer alkaloids from trees: development into drugs," Pharmacognosy Reviews, vol. 10, no. 20, pp. 90-99, 2016.

[9] E. Martino, G. Casamassima, S. Castiglione et al., "Vinca alkaloids and analogues as anti-cancer agents: looking back, peering ahead," Bioorganic \& Medicinal Chemistry Letters, vol. 28, no. 17, pp. 2816-2826, 2018.

[10] Drugbank, 2021, https://go.drugbank.com/drugs/.

[11] S. J. Li, X. Zhang, X. H. Wang, and C. Q. Zhao, "Novel natural compounds from endophytic fungi with anticancer activity," European Journal of Medicinal Chemistry, vol. 156, pp. 316343, 2018. 
[12] M. D. Torres, G. P. Andrade, S. H. Sato et al., "Natural and redesigned wasp venom peptides with selective antitumoral activity," Beilstein Journal of Organic Chemistry, vol. 14, no. 1, pp. 1693-1703, 2018.

[13] J. al-Tamimi, A. Semlali, I. Hassan et al., "Samsum ant venom exerts anticancer activity through immunomodulation in vitro and in vivo," Cancer Biotherapy and Radiopharmaceuticals, vol. 33, no. 2, pp. 65-73, 2018.

[14] M. Badolato, G. Carullo, E. Cione, F. Aiello, and M. C. Caroleo, "From the hive: honey, a novel weapon against cancer," European Journal of Medicinal Chemistry, vol. 142, pp. 290-299, 2017.

[15] F. Ahmad, P. Seerangan, M. Z. Mustafa, Z. F. Osman, J. M. Abdullah, and Z. Idris, "Anti-cancer properties of Heterotrigona itama sp. honey via induction of apoptosis in malignant glioma cells," Malaysian Journal of Medical Sciences, vol. 26, no. 2, pp. 30-39, 2019.

[16] M. J. Desamero, S. Kakuta, Y. Tang et al., "Tumor-suppressing potential of stingless bee propolis in in vitro and in vivo models of differentiated-type gastric adenocarcinoma," Scientific Reports, vol. 9, no. 1, article 19635, 2019.

[17] C. Sepúlveda, O. Núñez, A. Torres, L. Guzmán, and S. Wehinger, "Antitumor activity of propolis: recent advances in cellular perspectives, animal models and possible applications," Food Reviews International, vol. 36, no. 5, pp. 429-455, 2020.

[18] E. L. Ghisalberti, "Propolis: a review," Bee world, vol. 60, no. 2, pp. 59-84, 1979.

[19] G. A. Burdock, "Review of the biological properties and toxicity of bee propolis (propolis)," Food and Chemical Toxicology, vol. 36, no. 4, pp. 347-363, 1998.

[20] S. I. Anjum, A. Ullah, K. A. Khan et al., "Composition and functional properties of propolis (bee glue): a review," Saudi Journal of Biological Sciences, vol. 26, no. 7, pp. 1695-1703, 2019.

[21] S. Kumazawa, T. Hamasaka, and T. Nakayama, “Antioxidant activity of propolis of various geographic origins," Food Chemistry, vol. 84, no. 3, pp. 329-339, 2004.

[22] Y. Z. Zheng, G. Deng, Q. Liang, D. F. Chen, R. Guo, and R. C. Lai, "Antioxidant activity of quercetin and its glucosides from propolis: a theoretical study," Scientific Reports, vol. 7, no. 1, pp. 7543-7611, 2017.

[23] V. Dimov, N. Ivanovska, N. Manolova, V. Bankova, N. Nikolov, and S. Popov, "Immunomodulatory action of propolis. Influence on anti-infectious protection and macrophage function," Apidologie, vol. 22, no. 2, pp. 155-162, 1991.

[24] M. Al-Hariri, "Immune's-boosting agent: immunomodulation potentials of propolis," Journal of Family \& Community Medicine, vol. 26, no. 1, pp. 57-60, 2019.

[25] Y. K. Park, M. H. Koo, J. A. Abreu, M. Ikegaki, J. A. Cury, and P. L. Rosalen, "Antimicrobial activity of propolis on oral microorganisms," Current Microbiology, vol. 36, no. 1, pp. 24-28, 1998.

[26] R. S. Veiga, S. de Mendonça, P. B. Mendes et al., "Artepillin C and phenolic compounds responsible for antimicrobial and antioxidant activity of green propolis and Baccharis dracunculifolia DC," Journal of Applied Microbiology, vol. 122, no. 4, pp. 911-920, 2017.

[27] D. Grunberger, R. Banerjee, K. Eisinger et al., "Preferential cytotoxicity on tumor cells by caffeic acid phenethyl ester isolated from propolis," Experientia, vol. 44, no. 3, pp. 230-232, 1988.

[28] S. Patel, "Emerging adjuvant therapy for cancer: propolis and its constituents," Journal of Dietary Supplements, vol. 13, no. 3, pp. $245-268,2016$.
[29] H. F. Chiu, Y. C. Han, Y. C. Shen, O. Golovinskaia, K. Venkatakrishnan, and C. K. Wang, "Chemopreventive and chemotherapeutic effect of propolis and its constituents: a mini-review," Journal of Cancer Prevention, vol. 25, no. 2, pp. 70-78, 2020.

[30] H. Doğan, S. Silici, and A. A. Ozcimen, "Biological effects of propolis on cancer," Turkish Journal of Food and Agriculture Sciences, vol. 8, no. 3, pp. 573-579, 2020.

[31] E. W. Sayers, J. Beck, E. E. Bolton et al., "Database resources of the National Center for Biotechnology Information," Nucleic acids research, vol. 49, no. D1, pp. D10-D17, 2021.

[32] C. D. Michener, The bees of the world, The Johns Hopkins University Press, Baltimore, 2007.

[33] C. Rasmussen and S. A. Cameron, "Global stingless bee phylogeny supports ancient divergence, vicariance, and long distance dispersal," Biological Journal of the Linnean Society, vol. 99, no. 1, pp. 206-232, 2010.

[34] P. Nugitrangson, S. Puthong, T. Iempridee, W. Pimtong, S. Pornpakakul, and C. Chanchao, "In vitro and in vivo characterization of the anticancer activity of Thai stingless bee (Tetragonula laeviceps) cerumen," Experimental Biology and Medicine, vol. 241, no. 2, pp. 166-176, 2016.

[35] A. R. Bartolomeu, Y. Frión-Herrera, L. M. da Silva, G. G. Romagnoli, D. E. de Oliveira, and J. M. Sforcin, "Combinatorial effects of geopropolis produced by Melipona fasciculata Smith with anticancer drugs against human laryngeal epidermoid carcinoma (HEp-2) cells," Biomedicine \& Pharmacotherapy, vol. 81, pp. 48-55, 2016.

[36] T. Bonamigo, J. F. Campos, T. M. Alfredo et al., "Antioxidant, cytotoxic, and toxic activities of propolis from two native bees in Brazil: Scaptotrigona depilis and Melipona quadrifasciata anthidioides," Oxidative Medicine and Cellular Longevity, vol. 2017, Article ID 1038153, 12 pages, 2017.

[37] K. Utispan, B. Chitkul, and S. Koontongkaew, "Cytotoxic activity of propolis extracts from the stingless bee Trigona sirindhornae against primary and metastatic head and neck cancer cell lines," Asian Pacific Journal of Cancer Prevention, vol. 18, no. 4, pp. 1051-1055, 2017.

[38] F. A. Tomás-Barberán, C. García-Viguera, P. Vit-Olivier, F. Ferreres, and F. Tomás-Lorente, "Phytochemical evidence for the botanical origin of tropical propolis from Venezuela," Phytochemistry, vol. 34, no. 1, pp. 191-196, 1993.

[39] I. Kujumgiev, Y. S. Tsvetkova, Y. Serkedjieva, V. Bankova, R. Christov, and S. Popov, "Antibacterial, antifungal and antiviral activity of propolis of different geographic origin," Journal of Ethnopharmacology, vol. 64, no. 3, pp. 235-240, 1999.

[40] V. S. Bankova, S. L. de Castro, and M. C. Marcucci, "Propolis: recent advances in chemistry and plant origin," Apidologie, vol. 31, no. 1, pp. 3-15, 2000.

[41] V. Bankova and M. Popova, "Propolis of stingless bees: a promising source of biologically active compounds," Pharmacognosy Reviews, vol. 1, no. 1, pp. 37-101, 2007.

[42] F. C. Lavinas, E. H. B. Macedo, G. B. Sá et al., "Brazilian stingless bee propolis and geopropolis: promising sources of biologically active compounds," Revista Brasileira de Farmacognosia, vol. 29, no. 3, pp. 389-399, 2019.

[43] M. Popova, B. Trusheva, and V. Bankova, "Propolis of stingless bees: a phytochemist's guide through the jungle of tropical biodiversity," Phytomedicine, vol. 86, article 153098, 2021.

[44] E. W. Teixeira, G. Negri, R. M. Meira, D. Message, and A. Salatino, "Plant origin of green propolis: bee behavior, 
plant anatomy and chemistry," Evidence-Based Complementary and Alternative Medicine, vol. 2, no. 1, p. 92, 2005.

[45] R. Silva-Carvalho, F. Baltazar, and C. Almeida-Aguiar, "Propolis: a complex natural product with a plethora of biological activities that can be explored for drug development," Evidence-Based Complementary and Alternative Medicine, vol. 2015, Article ID 206439, 29 pages, 2015.

[46] M. Simone-Finstrom and M. Spivak, "Propolis and bee health: the natural history and significance of resin use by honey bees," Apidologie, vol. 41, no. 3, pp. 295-311, 2010.

[47] J. M. Sforcin and V. Bankova, "Propolis: is there a potential for the development of new drugs?," Journal of Ethnopharmacology, vol. 133, no. 2, pp. 253-260, 2011.

[48] V. C. Toreti, H. H. Sato, G. M. Pastore, and Y. K. Park, "Recent progress of propolis for its biological and chemical compositions and its botanical origin," Evidence-Based Complementary and Alternative Medicine, vol. 2013, Article ID 697390, 13 pages, 2013.

[49] M. Lotfy, "Biological activity of bee propolis in health and disease," Asian Pacific Journal of Cancer Prevention, vol. 7, pp. 22-31, 2006.

[50] A. P. Farnesi, R. Aquino-Ferreira, D. de Jong, J. K. Bastos, and A. E. Soares, "Effects of stingless bee and honey bee propolis on four species of bacteria," Genetics and Molecular Research, vol. 8, no. 2, pp. 635-640, 2009.

[51] M. K. Choudhari, S. A. Punekar, R. V. Ranade, and K. M. Paknikar, "Antimicrobial activity of stingless bee (Trigona sp.) propolis used in the folk medicine of Western Maharashtra, India," Journal of Ethnopharmacology, vol. 141, no. 1, pp. 363-367, 2012.

[52] A. C. Sawaya, J. C. Calado, L. D. Santos et al., "Composition and antioxidant activity of propolis from three species of Scaptotrigona stingless bees," Journal of ApiProduct and ApiMedical Science, vol. 1, no. 2, pp. 37-42, 2009.

[53] A. R. Torres, L. P. Sandjo, M. T. Friedemann et al., "Chemical characterization, antioxidant and antimicrobial activity of propolis obtained from Melipona quadrifasciata quadrifasciata and Tetragonisca angustula stingless bees," Brazilian Journal of Medical and Biological Research, vol. 51, no. 6, pp. e7118-e7210, 2018.

[54] F. C. Massaro, P. R. Brooks, H. M. Wallace, and F. D. Russell, "Cerumen of Australian stingless bees (Tetragonula carbonaria): gas chromatography-mass spectrometry fingerprints and potential anti-inflammatory properties," Naturwissenschaften, vol. 98, no. 4, pp. 329-337, 2011.

[55] J. F. Campos, U. P. Santos, P. S. Rocha et al., "Antimicrobial, antioxidant, anti-inflammatory, and cytotoxic activities of propolis from the stingless bee Tetragonisca fiebrigi (Jataí)," Evidence-Based Complementary and Alternative Medicine, vol. 2015, Article ID 296186, 11 pages, 2015.

[56] M. K. Choudhari, R. Haghniaz, J. M. Rajwade, and K. M. Paknikar, "Anticancer activity of Indian stingless bee propolis: an in vitro study," Evidence-Based Complementary and Alternative Medicine, vol. 2013, Article ID 928280, 10 pages, 2013.

[57] J. Cisilotto, L. P. Sandjo, L. G. Faqueti et al., "Cytotoxicity mechanisms in melanoma cells and UPLC- QTOF/MS ${ }^{2}$ chemical characterization of two Brazilian stingless bee propolis: Uncommon presence of piperidinic alkaloids," Journal of Pharmaceutical and Biomedical Analysis, vol. 149, pp. 502511, 2018.
[58] J. F. Campos, U. P. dos Santos, L. F. Macorini et al., “Antimicrobial, antioxidant and cytotoxic activities of propolis from Melipona orbignyi (Hymenoptera, Apidae)," Food and Chemical Toxicology, vol. 65, pp. 374-380, 2014.

[59] G. Kroemer, L. Galluzzi, P. Vandenabeele et al., "Classification of cell death: recommendations of the Nomenclature Committee on Cell Death 2009," Cell Death and Differentiation, vol. 16, no. 1, pp. 3-11, 2009.

[60] M. A. Sanches, A. M. S. Pereira, and J. E. Serrão, "Pharmacological actions of extracts of propolis of stingless bees (Meliponini)," Journal of Apicultural Research, vol. 56, no. 1, pp. 50-57, 2017.

[61] Y. Barlak, O. Değer, M. Çolak, S. Karataylı, A. Bozdayı, and F. Yücesan, "Effect of Turkish propolis extracts on proteome of prostate cancer cell line," Proteome Science, vol. 9, no. 1, pp. 74-111, 2011.

[62] N. Hueso-Falcón, P. V. Girón, P. Velasco et al., "Synthesis and induction of apoptosis signaling pathway of ent-kaurane derivatives," Bioorganic \& Medicinal Chemistry, vol. 18, no. 4, pp. 1724-1735, 2010.

[63] E. B. Souto, A. Zielinska, S. B. Souto et al., "(+)-Limonene 1, 2-epoxide-loaded SLNs: evaluation of drug release, antioxidant activity, and cytotoxicity in an $\mathrm{HaCaT}$ cell line," International Journal of Molecular Sciences, vol. 21, no. 4, pp. 14491511, 2020.

[64] D. Cox-Georgian, N. Ramadoss, C. Dona, and C. Basu, "Therapeutic and Medicinal Uses of Terpenes," in Medicinal Plants: From Farm to Pharmacy, N. Joshee, S. Dhekney, and P. Parajuli, Eds., pp. 333-359, Springer, Cham, 2019.

[65] T. Zhang, W. Chen, X. Jiang et al., "Anticancer effects and underlying mechanism of colchicine on human gastric cancer cell lines in vitro and in vivo," Bioscience Reports, vol. 39, no. 1, pp. 1-10, 2019.

[66] M. Abotaleb, A. Liskova, P. Kubatka, and D. Büsselberg, "Therapeutic potential of plant phenolic acids in the treatment of cancer," Biomolecules, vol. 10, no. 2, pp. 221-223, 2020.

[67] H. Tsai, C. Ho, and Y. Chen, "Biological actions and molecular effects of resveratrol, pterostilbene, and $3^{\prime}$-hydroxypterostilbene," Journal of Food and Drug Analysis, vol. 25, no. 1, pp. 134-147, 2017.

[68] S. Umthong, P. Phuwapraisirisan, S. Puthong, and C. Chanchao, "In vitro antiproliferative activity of partially purified Trigona laeviceps propolis from Thailand on human cancer cell lines," BMC complementary and alternative medicine, vol. 11, no. 1, pp. 1-8, 2011.

[69] P. M. Kustiawan, S. Puthong, E. T. Arung, and C. Chanchao, "In vitro cytotoxicity of Indonesian stingless bee products against human cancer cell lines," Asian Pacific Journal of Tropical Biomedicine, vol. 4, no. 7, pp. 549-556, 2014.

[70] S. Kothai and B. Jayanthi, "Anti cancer activity of silver nano particles bio- synthesized using stingless bee propolis (Tetragonula iridipennis) of Tamilnadu," Asian Journal of Biomedical and Pharmaceutical Sciences, vol. 4, no. 40, pp. 30-37, 2015.

[71] P. M. Kustiawan, K. Lirdprapamongkol, T. Palaga et al., "Molecular mechanism of cardol, isolated from Trigona incisa stingless bee propolis, induced apoptosis in the SW620 human colorectal cancer cell line," BMC Pharmacology and Toxicology, vol. 18, no. 1, pp. 32-110, 2017.

[72] H. X. Nguyen, M. T. Nguyen, N. T. Nguyen, and S. Awale, "Chemical constituents of propolis from Vietnamese Trigona 
minor and their antiausterity activity against the panc-1 human pancreatic cancer cell line," Journal of Natural Products, vol. 80, no. 8, pp. 2345-2352, 2017.

[73] N. A. Mohd-Yazid, N. B. M. Zin, N. Pauzi, and K. S. Mohd, "Preliminary evaluation of antioxidant and cytotoxic activity of ethanolic extract of stingless bees propolis from different localities," Journal of Agrobiotechnology, vol. 9, no. 1S, pp. 132-141, 2018.

[74] M. Iqbal, T. P. Fan, D. Watson, S. Alenezi, K. Saleh, and M. Sahlan, "Preliminary studies: the potential antiangiogenic activities of two Sulawesi Island (Indonesia) propolis and their chemical characterization," Heliyon, vol. 5, no. 7, article e01978, 2019.

[75] E. Amalia, A. Diantini, and A. Subarnas, "Water-soluble propolis and bee pollen of Trigona spp. from South Sulawesi Indonesia induce apoptosis in the human breast cancer MCF-7 cell line," Oncology Letters, vol. 20, no. 5, pp. 1-10, 2020.

[76] W. A. S. Mohamed, N. Z. Ismail, E. A. Omar, N. Abdul Samad, S. K. Adam, and S. Mohamad, "GC-MS evaluation, antioxidant content, and cytotoxic activity of propolis extract from Peninsular Malaysian stingless bees, Tetrigona apicalis," Evidence-Based Complementary and Alternative Medicine, vol. 2020, Article ID 8895262, 9 pages, 2020.

[77] T. Bonamigo, J. F. Campos, A. S. Oliveira et al., "Antioxidant and cytotoxic activity of propolis of Plebeia droryana and Apis mellifera (Hymenoptera, Apidae) from the Brazilian Cerrado biome," PloS One, vol. 12, no. 9, article e0183983, 2017.

[78] B. Vongsak, C. Chonanant, and S. Machana, "In vitro cytotoxicity of Thai stingless bee propolis from Chanthaburi orchard," Walailak Journal of Science and Technology, vol. 14, no. 9, pp. 741-747, 2017.

[79] S. Orrenius, V. Gogvadze, and B. Zhivotovsky, "Calcium and mitochondria in the regulation of cell death," Biochemical and Biophysical Research Communications, vol. 460, no. 1, pp. 72-81, 2015.

[80] P. Pinton, C. Giorgi, R. Siviero, E. Zecchini, and R. Rizzuto, "Calcium and apoptosis: ER-mitochondria $\mathrm{Ca}^{2+}$ transfer in the control of apoptosis," Oncogene, vol. 27, no. 50, pp. 6407-6418, 2008.

[81] B. Zhivotovsky and S. Orrenius, "Calcium and cell death mechanisms: a perspective from the cell death community," Cell Calcium, vol. 50, no. 3, pp. 211-221, 2011.

[82] P. E. Czabotar, G. Lessene, A. Strasser, and J. M. Adams, "Control of apoptosis by the BCL-2 protein family: implications for physiology and therapy," Nature Reviews Molecular Cell Biology, vol. 15, no. 1, pp. 49-63, 2014.

[83] S. Emanuele, E. Oddo, A. D’Anneo et al., "Routes to cell death in animal and plant kingdoms: from classic apoptosis to alternative ways to die-a review," Rendiconti Lincei Scienze Fisiche e Naturali, vol. 29, no. 2, pp. 397-409, 2018.

[84] M. S. D'arcy, "Cell death: a review of the major forms of apoptosis, necrosis and autophagy," Cell Biology International, vol. 43, no. 6, pp. 582-592, 2019.

[85] T. V. Berghe, N. Vanlangenakker, E. Parthoens et al., "Necroptosis, necrosis and secondary necrosis converge on similar cellular disintegration features," Cell Death and Differentiation, vol. 17, no. 6, pp. 922-930, 2010.

[86] T. vanden Berghe, W. J. Kaiser, M. J. Bertrand, and P. Vandenabeele, "Molecular crosstalk between apoptosis, necroptosis, and survival signaling," Molecular \& Cellular Oncology, vol. 2, no. 4, article e975093, 2015.

[87] V. A. Patel, A. Longacre, K. Hsiao et al., "Apoptotic Cells, at All Stages of the Death Process, Trigger Characteristic Signaling Events That Are Divergent from and Dominant over Those Triggered by Necrotic Cells:," Journal of Biological Chemistry, vol. 281, no. 8, pp. 4663-4670, 2006.

[88] T. V. Berghe, A. Linkermann, S. Jouan-Lanhouet, H. Walczak, and P. Vandenabeele, "Regulated necrosis: the expanding network of non-apoptotic cell death pathways," Nature Reviews Molecular Cell Biology, vol. 15, no. 2, pp. 135-147, 2014.

[89] M. Pasparakis and P. Vandenabeele, "Necroptosis and its role in inflammation," Nature, vol. 517, no. 7534, pp. 311-320, 2015.

[90] P. Vandenabeele, L. Galluzzi, T. vanden Berghe, and G. Kroemer, "Molecular mechanisms of necroptosis: an ordered cellular explosion," Nature Reviews Molecular Cell Biology, vol. 11, no. 10, pp. 700-714, 2010.

[91] M. Sauler, I. S. Bazan, and P. J. Lee, "Cell death in the lung: the apoptosis-necroptosis axis," Annual Review of Physiology, vol. 81, no. 1, pp. 375-402, 2019.

[92] Y. Zhang, X. Chen, C. Gueydan, and J. Han, "Plasma membrane changes during programmed cell deaths," Cell Research, vol. 28, no. 1, pp. 9-21, 2018.

[93] M. H. Orzalli and J. C. Kagan, "Apoptosis and necroptosis as host defense strategies to prevent viral infection," Trends in Cell Biology, vol. 27, no. 11, pp. 800-809, 2017.

[94] E. W. Seo, H. S. Lee, H. Sung et al., "CHIP controls necroptosis through ubiquitylation- and lysosome-dependent degradation of RIPK3," Nature Cell Biology, vol. 18, no. 3, pp. 291-302, 2016.

[95] S. Grootjans, T. vanden Berghe, and P. Vandenabeele, "Initiation and execution mechanisms of necroptosis: an overview," Cell Death and Differentiation, vol. 24, no. 7, pp. 1184-1195, 2017.

[96] B. Shan, H. Pan, A. Najafov, and J. Yuan, "Necroptosis in development and diseases," Genes \& Development, vol. 32, no. 5-6, pp. 327-340, 2018.

[97] Z. Cai, S. Jitkaew, J. Zhao et al., "Plasma membrane translocation of trimerized MLKL protein is required for TNF-induced necroptosis," Nature cell biology, vol. 16, no. 1, pp. 55-65, 2014.

[98] T. Molnár, A. Mázló, V. Tslaf, A. G. Szöllősi, G. Emri, and G. Koncz, "Current translational potential and underlying molecular mechanisms of necroptosis," Cell Death and Disease, vol. 10, no. 11, pp. 860-921, 2019.

[99] L. S. Long and K. M. Ryan, "New frontiers in promoting tumour cell death: targeting apoptosis, necroptosis and autophagy," Oncogene, vol. 31, no. 49, pp. 5045-5060, 2012.

[100] P. M. Kustiawan, P. Phuwapraisirisan, S. Puthong, T. Palaga, E. T. Arung, and C. Chanchao, "Propolis from the stingless bee Trigona incisa from East Kalimantan, Indonesia, induces in vitro cytotoxicity and apoptosis in cancer cell lines," Asian Pacific Journal of Cancer Prevention, vol. 16, no. 15, pp. 65816589, 2015.

[101] C. Rogers, T. Fernandes-Alnemri, L. Mayes, D. Alnemri, G. Cingolani, and E. S. Alnemri, "Cleavage of DFNA5 by caspase-3 during apoptosis mediates progression to secondary necrotic/pyroptotic cell death," Nature Communications, vol. 8, no. 1, article 14128, pp. 1-14, 2017. 
[102] S. Elmore, "Apoptosis: a review of programmed cell death," Toxicologic Pathology, vol. 35, no. 4, pp. 495-516, 2007.

[103] S. H. Suhaili, H. Karimian, M. Stellato, T. H. Lee, and M. I. Aguilar, "Mitochondrial outer membrane permeabilization: a focus on the role of mitochondrial membrane structural organization," Biophysical Reviews, vol. 9, no. 4, pp. 443457, 2017.

[104] Y. Imoto, Y. Yoshida, F. Yagisawa, H. Kuroiwa, and T. Kuroiwa, "The cell cycle, including the mitotic cycle and organelle division cycles, as revealed by cytological observations," Journal of Electron Microscopy, vol. 60, supplement 1, pp. S117-S136, 2011.

[105] L. C. Leal-Esteban and L. Fajas, "Cell cycle regulators in cancer cell metabolism," Biochimica et Biophysica ActaMolecular Basis of Disease, vol. 1866, no. 5, article 165715, 2020.

[106] B. Jingwen, L. Yaochen, and Z. Guojun, "Cell cycle regulation and anticancer drug discovery," Cancer Biology \& Medicine, vol. 14, no. 4, pp. 348-362, 2017.

[107] T. Otto and P. Sicinski, "Cell cycle proteins as promising targets in cancer therapy," Nature Reviews Cancer, vol. 17, no. 2, pp. 93-115, 2017.

[108] S. Lim and P. Kaldis, "Cdks, cyclins and CKIs: roles beyond cell cycle regulation," Development, vol. 140, no. 15, pp. 3079-3093, 2013.

[109] R. Roskoski Jr., "Cyclin-dependent protein serine/threonine kinase inhibitors as anticancer drugs," Pharmacological Research, vol. 139, pp. 471-488, 2019.

[110] N. Hustedt and D. Durocher, "The control of DNA repair by the cell cycle," Nature Cell Biology, vol. 19, no. 1, pp. 1-9, 2017.

[111] Y. A. Sonawane, M. A. Taylor, J. V. Napoleon, S. Rana, J. I. Contreras, and A. Natarajan, "Cyclin dependent kinase 9 inhibitors for cancer Therapy," Journal of Medicinal Chemistry, vol. 59, no. 19, pp. 8667-8684, 2016.

[112] M. Salazar-Roa and M. Malumbres, "Fueling the cell division cycle," Trends in Cell Biology, vol. 27, no. 1, pp. 69-81, 2017.

[113] K. Engeland, "Cell cycle arrest through indirect transcriptional repression by p53: I have a DREAM," Cell Death and Differentiation, vol. 25, no. 1, pp. 114-132, 2018.

[114] Y. Karimian, Y. Ahmadi, and B. Yousefi, "Multiple functions of p21 in cell cycle, apoptosis and transcriptional regulation after DNA damage," DNA repair, vol. 42, pp. 63-71, 2016.

[115] R. Roskoski Jr., "Cyclin-dependent protein kinase inhibitors including palbociclib as anticancer drugs," Pharmacological Research, vol. 107, pp. 249-275, 2016.

[116] A. Grison and S. Atanasoski, "Cyclins, cyclin-dependent kinases, and cyclin-dependent kinase inhibitors in the mouse nervous system," Molecular Neurobiology, vol. 57, no. 7, pp. 3206-3218, 2020.

[117] H. G. Qin, F. D. W. Reddy, F. D. Weinberg, and G. P. Kalemkerian, "Cyclin-dependent kinase inhibitors for the treatment of lung cancer," Expert Opinion on Pharmacotherapy, vol. 21, no. 8, pp. 941-952, 2020.

[118] K. T. S. Santo, K. T. Siu, and N. Raje, "Targeting cyclindependent kinases and cell cycle progression in human cancers," Seminars in Oncology, vol. 42, no. 6, pp. 788-800, 2015.

[119] M. J. Sánchez-Martínez, S. G. Lallena, S. G. Sanfeliciano, and A. de Dios, "Cyclin dependent kinase (CDK) inhibitors as anticancer drugs: Recent advances (2015-2019)," Bioorganic
\& Medicinal Chemistry Letters, vol. 29, no. 20, article 126637, 2019.

[120] J. S. Blachly, J. C. Byrd, and M. Grever, "Cyclin-dependent kinase inhibitors for the treatment of chronic lymphocytic leukemia," Seminars in Oncology, vol. 43, no. 2, pp. 265273, 2016.

[121] L. M. Sánchez-Martínez, M. J. Gelbert, M. J. Lallena, and A. de Dios, "Cyclin dependent kinase (CDK) inhibitors as anticancer drugs," Bioorganic \& Medicinal Chemistry Letters, vol. 25, no. 17, pp. 3420-3435, 2015.

[122] C. Bonofiglio, C. Giordano, F. de Amicis, M. Lanzino, and S. Andò, "Natural products as promising antitumoral agents in breast cancer: mechanisms of action and molecular targets," Mini-Reviews in Medicinal Chemistry, vol. 16, no. 8, pp. 596-604, 2016.

[123] L. D. Li, K. H. Li, and J. T. Li, “TP53 mutations as potential prognostic markers for specific cancers: analysis of data from The Cancer Genome Atlas and the International Agency for Research on Cancer TP53 Database," Journal of Cancer Research and Clinical Oncology, vol. 145, no. 3, pp. 625636, 2019.

[124] S. Yamamoto and T. Iwakuma, "Regulators of oncogenic mutant TP53 gain of function," Cancers, vol. 11, no. 1, pp. 4-26, 2019.

[125] M. C. Casimiro, M. Velasco-Velázquez, C. Aguirre-Alvarado, and R. G. Pestell, "Overview of cyclins D1 function in cancer and the CDK inhibitor landscape: past and present," Expert Opinion on Investigational Drugs, vol. 23, no. 3, pp. 295304, 2014.

[126] R. Perona, "Cell signalling: growth factors and tyrosine kinase receptors," Clinical and Translational Oncology, vol. 8, no. 2, pp. 77-82, 2006.

[127] T. Regad, "Targeting RTK signaling pathways in cancer," Cancers, vol. 7, no. 3, pp. 1758-1784, 2015.

[128] My Cancer Genome Database, 2020, https://www .mycancergenome.org/content/pathways/receptor-tyrosinekinase-growth-factor-signaling/.

[129] M. A. Lemmon and J. Schlessinger, "Cell signaling by receptor tyrosine kinases," Cell, vol. 141, no. 7, pp. 1117-1134, 2010.

[130] B. Vogelstein, N. Papadopoulos, V. E. Velculescu, S. Zhou, L. A. Diaz, and K. W. Kinzler, "Cancer genome landscapes," Science, vol. 339, no. 6127, pp. 1546-1558, 2013.

[131] E. C. Lien, C. C. Dibble, and A. Toker, "PI3K signaling in cancer: beyond AKT," Current Opinion in Cell Biology, vol. 45, pp. 62-71, 2017.

[132] J. Polivka Jr. and F. Janku, "Molecular targets for cancer therapy in the PI3K/AKT/mTOR pathway," Pharmacology \& Therapeutics, vol. 142, no. 2, pp. 164-175, 2014.

[133] I. A. Mayer and C. L. Arteaga, "The PI3K/AKT pathway as a target for cancer treatment," Annual Review of Medicine, vol. 67, no. 1, pp. 11-28, 2016.

[134] S. A. Danielsen, P. W. Eide, A. Nesbakken, T. Guren, E. Leithe, and R. A. Lothe, "Portrait of the PI3K/AKT pathway in colorectal cancer," Biochimica et Biophysica Acta. Reviews on Cancer, vol. 1855, no. 1, pp. 104-121, 2015.

[135] B. Liu, X. Wu, B. Liu et al., "MiR-26a enhances metastasis potential of lung cancer cells via AKT pathway by targeting PTEN," Biochimica et Biophysica Acta-Molecular Basis of Disease, vol. 1822, no. 11, pp. 1692-1704, 2012. 
[136] K. Mortezaee and N. Khanlarkhani, "Melatonin application in targeting oxidative-induced liver injuries: a review," Journal of Cellular Physiology, vol. 233, no. 5, pp. 4015-4032, 2018.

[137] A. André-Lévigne, M. S. P. Modarressi, M. Pepper, and B. Pittet-Cuénod, "Reactive oxygen species and NOX enzymes are emerging as key players in cutaneous wound repair," International Journal of Molecular Sciences, vol. 18, no. 10, pp. 2149-2228, 2017.

[138] L. Andrisic, D. Dudzik, C. Barbas, L. Milkovic, T. Grune, and N. Zarkovic, "Short overview on metabolomics approach to study pathophysiology of oxidative stress in cancer," Redox Biology, vol. 14, pp. 47-58, 2018.

[139] G. Barrera, "Oxidative stress and lipid peroxidation products in cancer progression and therapy," ISRN Oncology, vol. 2012, Article ID 137289, 21 pages, 2012.

[140] B. F. Zamarron and W. Chen, "Dual roles of immune cells and their factors in cancer development and progression," International Journal of Biological Sciences, vol. 7, no. 5, pp. 651-658, 2011.

[141] M. Landskron, M. de la Fuente, P. Thuwajit, C. Thuwajit, and M. A. Hermoso, "Chronic inflammation and cytokines in the tumor microenvironment," Journal of Immunology Research, vol. 2014, Article ID 149185, 19 pages, 2014.

[142] S. Hochheim, A. Guedes, L. Faccin-Galhardi et al., "Determination of phenolic profile by HPLC-ESI-MS/MS, antioxidant activity, in vitro cytotoxicity and anti-herpetic activity of propolis from the Brazilian native bee Melipona quadrifasciata," Revista Brasileira de Farmacognosia, vol. 29, no. 3, pp. 339-350, 2019.

[143] F. Gentile, A. Arcaro, S. Pizzimenti et al., "DNA damage by lipid peroxidation products: implications in cancer, inflammation and autoimmunity," AIMS Genetics, vol. 4, no. 2, pp. 103-137, 2017.

[144] A. Costa, A. Scholer-Dahirel, and F. Mechta-Grigoriou, "The role of reactive oxygen species and metabolism on cancer cells and their microenvironment," Seminars in Cancer Biology, vol. 25, pp. 23-32, 2014.

[145] S. Prasad, S. C. Gupta, and A. K. Tyagi, "Reactive oxygen species (ROS) and cancer: role of antioxidative nutraceuticals," Cancer Letters, vol. 387, pp. 95-105, 2017.

[146] K. D. Hamilton, P. R. Brooks, S. M. Ogbourne, and F. D. Russell, "Natural products isolated from Tetragonula carbonaria cerumen modulate free radical-scavenging and 5lipoxygenase activities in vitro," BMC complementary and alternative medicine, vol. 17, no. 1, pp. 232-238, 2017.

[147] D. Tewari, S. F. Nabavi, S. M. Nabavi et al., "Targeting activator protein 1 signaling pathway by bioactive natural agents: possible therapeutic strategy for cancer prevention and intervention," Pharmacological Research, vol. 128, pp. 366-375, 2018.

[148] V. Schirrmacher, "From chemotherapy to biological therapy: a review of novel concepts to reduce the side effects of systemic cancer treatment (review)," International Journal of Oncology, vol. 54, no. 2, pp. 407-419, 2019.

[149] E. Galeano, E. Nieto, A. I. García-Pérez, M. D. Delgado, M. Pinilla, and P. Sancho, "Effects of the antitumoural dequalinium on NB4 and K562 human leukemia cell lines: Mitochondrial implication in cell death," Leukemia Research, vol. 29, no. 10, pp. 1201-1211, 2005.
[150] V. Velikova, M. C. Bankova, I. Marcucci, I. Tsvetkova, and A. Kujumgiev, "Chemical composition and biological activity of propolis from Brazilian meliponinae," Zeitschrift für Naturforschung C.-Journal of Biosciences, vol. 55, no. 9-10, pp. 785-789, 2000.

[151] P. R. Hunt, “The C. elegans model in toxicity testing," Journal of Applied Toxicology, vol. 37, no. 1, pp. 50-59, 2017.

[152] T. Monteiro-Alfredo, P. Matafome, B. P. Iacia et al., “Acrocomia aculeata (Jacq.) Lodd. ex Mart. leaves increase SIRT1 levels and improve stress resistance," Oxidative Medicine and Cellular Longevity, vol. 2020, Article ID 5238650, 16 pages, 2020.

[153] the International Natural Product Sciences Taskforce, A. G. Atanasov, S. B. Zotchev, V. M. Dirsch, and C. T. Supuran, "Natural products in drug discovery: advances and opportunities," Nature Reviews-Drug Discovery, vol. 20, no. 3, pp. 200-216, 2021.

[154] D. Kashyap, H. S. Tuli, M. B. Yerer et al., "Natural productbased nanoformulations for cancer therapy: opportunities and challenges," Seminars in Cancer Biology, vol. 69, pp. 523, 2021.

[155] W. Khongkaew and W. Chaemsawang, "Development and characterization of stingless bee propolis properties for the development of solid lipid nanoparticles for loading lipophilic substances," International Journal of Biomaterials, vol. 2021, Article ID 6662867, 10 pages, 2021. 